\title{
Nadahnuće i istina Svetoga pisma
}

\author{
Hrvoje KALEM* \\ • https://doi.org/10.31823/d.27.3.6 • \\ UDK: 27-23-73 • Pregledni članak \\ Primljeno: 5. listopada 2018. • Prihvaćeno: 9. rujna 2019.
}

${ }^{*}$ Dr. sc. Hrvoje Kalem,

Katolički bogoslovni

fakultet u Đakovu

Sveučilišta J. J.

Strossmayera u Osijeku,

P. Preradovića 17, p. p. 54, 31400 Đakovo, Hrvatska,

Sažetak: P romišljanje o nadahnuću $i$ istini Svetoga pisma neizostav n a je tema u gotovo svakom razdoblju crkvenoga učiteljstva i teologije. Prvi dio clanka tematizira narav nadahnuća i način na koji se ono tumači upozoravajući na njegovo šire poimanje u kasnijim crkvenim dokumentima: dogmatskoj konstituciji o božanskoj objavi Drugoga vatikanskoga sabora Dei Verbum te osobito u dokumentu Papinske biblijske komisije iz 2014. godine naslovljenom Istina i nadahnuće Svetoga pisma. Riječ koja dolazi od Boga i koja govori o Bogu da spasi svijet. Članak upozorava na važnost nadahnuća kao nosivoga pojma za razumijevanje svetoga teksta kao uistinu Božje riječi u ljudskim riječima. S tom stvarnošću neodvojivo je vezana istina Svetoga pisma. U drugome dijelu clanak pojašnjava da je istina koju trebamo tražiti u Svetome pismu te zbog koje ono postoji ona istina koja je u njemu zapisana radi našega spasenja, čime se izriče pozitivan stav glede teme istine Svetoga pisma. Ta je istina sva sažeta i u punini izrečena u osobi Isusa Krista, Očeva objavitelja i Spasitelja čovječanstva. Nadahnuće se pokazuje kao prikladan put za priopćavanje upravo te istine.

Ključne riječi: istina, nadahnuće, Sveto pismo, spasenje, Riječ Božja, hagiografi, Drugi vatikanski koncil.

\section{Uvod}

Riječ Božja daruje nam se u Svetome pismu kao nadahnuto pisano svjedočanstvo objave. Objava, nadahnuće, kanon i istina Svetoga pisma neodvojivo su povezani i konstitutivni za razumijevanje Svetoga pisma kao Božje riječi, koja je u povijesti izrečena ljudskim govorom te zapisana ljudskim jezikom. Ti su elementi neizostavni i za herme- 
neutiku svetih tekstova. U našem radu posvetit ćemo se nadahnuću i istini Svetoga pisma, dvama konstitutivnim elementima po kojima, uz kanon, Sveto pismo jest objavljena Riječ Gospodnja, kako čitamo i proglašavamo u liturgiji Crkve.

Nadahnuće je ključni pojam za razumijevanje svetoga teksta kao Riječi Božje u ljudskim riječima. ${ }^{1}$ Posljedično, to implicira da je sve ono što je sadržano u Svetome pismu istina jer, ako je sveti tekst Bogom nadahnut, onda ne može sadržavati drugo doli istinu i samo istinu. To uvjerenje posve dijelimo, nakon što razaznamo o kakvoj je istini riječ u Svetome pismu: znanstvenoj, povijesnoj, matematičkoj, mehaničkoj, geografskoj ili pak istini koja je u Svetome pismu zapisana radi našega spasenja. S Drugim vatikanskim saborom to potonje uvjerenje posve je prevladalo u dokumentima crkvenoga učiteljstva, a prethodno i u teološkim promišljanjima. Time je postalo nedvosmisleno jasno o kakvoj je istini riječ u Svetome pismu, iako povijest teoloških promišljanja i crkveni dokumenti ne artikuliraju uvijek to uvjerenje na posve jasan način.

Naša je nakana kratko ocrtati povijesni obzor poimanja nadahnuća i istine Svetoga pisma. Ne ćemo ulaziti u profano značenje pojma nadahnuće ${ }^{2}$, nego, polazeći od tekstova Staroga i Novoga zavjeta te prateći daljnji razvoj i postupanje s tim pojmom, dospjeti do njegova aktualnoga razumijevanja. Bitna polazna točka našega promišljanja jest da Božju objavu, koja je sadržana u Svetome pismu i Tradiciji, možemo razumjeti samo kao Božji nezasluženi dar. Od kozmičke objave, preko objave u stvaranju, do one kojom Bog sklapa savez s pojedincima, pa onda i s cijelim narodom, možemo iščitavati Božju naklonost prema čovjeku, njegov dar ljubavi i čovjekoljublja. Time Bog već pokazuje svoju kenozu, svoj silazak i oplijenjivanje sama sebe te susretljivost kako bi zapodjenuo dijalog s čovjekom u korist čovjeka i njegova spasenja. Ako je Sveto pismo Božji dar i ako nam Bog progovara po njemu i kroz njega, tada je i nadahnuće Božji dar, kao i istina koja nam je priopćena u Svetome pismu. Nadahnuće i istinu Svetoga pisma trebamo promatrati u obzoru dara kojim Bog daruje sama sebe, oni pripadaju Božjem spasenjskom planu ${ }^{3}$ i znak su Božje vjernosti koja svoj vrhunac ima u utjelovljenome Sinu, definitivnoj ili konačnoj Božjoj Riječi.

Osjetljivost i još uvijek aktualnost poimanja nadahnuća, a s njime i istine Svetoga pisma pokazuje prijedlog XII. opće sinode biskupa iz 2008. godine Kongregaciji za nauk vjere da pojasni pojmove istina i nadahnuće Svetoga pisma te njihov međusobni odnos, kako bi se bolje shvatilo i razumjelo nauk sadržan u Dei Verbum,

\footnotetext{
${ }^{1}$ Usp. BENEDIKT XVI., Verbum Domini. Riječ Gospodnja, Zagreb, ${ }^{22011 . ~(=V D), ~ b r . ~} 19$.

${ }^{2}$ O tome vidi: M. LIMBECK, La Sacra Scrittura, u: W. KERN, H. J. POTTMEYER, M. SECKLER (ur.), Trattato di gnoseologia teologica 4, Brescia, 1990., 78., bilj. 38.

${ }^{3}$ Usp. M. C. APARICIO VALLS, Ispirazione, Assisi, 2014., 8.
} 
br.11. ${ }^{4}$ Taj odnos između istine i nadahnuća Svetoga pisma elaborirala je Papinska biblijska komisija te ga je 2014. godine objavila u dokumentu Nadahnuće i istina Svetoga pisma. Riječ koja dolazi od Boga i govori o Bogu da spasi svijet. Dakle, kada govorimo o promišljanjima s obzirom na našu temu, nezaobilazna je trijada crkvenih dokumenata Dei Verbum - Verbum Domini - Nadahnuće i istina Svetoga pisma. Oslanjajući se upravo na te dokumente, kao i na dokument Sveto pismo - Božji dar Katoličke biskupske konferencije Engleske i Walesa i Katoličke biskupske konferencije Škotske, te na relevantna promišljanja teologa, ocrtat ćemo okvir za ispravno razumijevanje nadahnuća i istine Svetoga pisma, ne misleći kako smo time posve iscrpili naš argument.

\section{Poimanje nadahnuća Svetoga pisma}

Pojmom nadahnuće Crkva izražava vjeru u činjenicu izvanrednoga djelovanja Duha Svetoga na hagiografe te time potvrđuje da je Sveto pismo Božje djelo i djelo određenih ljudi, odnosno da su istinski autori Svetoga pisma Bog i čovjek. ${ }^{5}$ Već bismo činjenicu da Bog izabire neke ljude i služi se njima mogli tumačiti kao nadahnuće jer biti izabran znači upravo biti zahvaćen Bogom, biti dodirnut Bogom. Onaj tko je zahvaćen Bogom ulazi u sferu božanskoga i tako postaje nadahnut Bogom $i$ sposoban prenositi i zapisati ono što je vidio, čuo i iskusio, kako je najčešće slučaj s prorocima. Uvjerenje da je Bog nadahnitelj i začetnik knjiga obaju zavjeta ${ }^{6}$ objašnjava se time da Bog izabire i nadahnjuje ljude koji onda kao pravi autori pismeno predaju samo ono što Bog hoće. ${ }^{7}$ Oni ne pišu po diktatu, nego su i sami pravi autori upravo zato što se služe svojim sposobnostima i vlastitim silama.

Biblija vrlo rijetko govori o pojmu nadahnuća. Stari zavjet ne poznaje taj termin, ali na vrlo eksplicitan način opisuje stvarnost nadahnuća. Promotrimo li Božje ophođenje prema ljudima u kontekstu njegova spasenjskoga plana, vidjet ćemo da je nadahnuće mnogo širi pojam od one karizme koju ima pojedini biblijski pisac. $\mathrm{Ne}$ možemo nadahnuće reducirati samo na ono koje postoji u pisanom obliku, dakle u zapisanoj Božjoj riječi, nego se ono proteže i na vrijeme prije zapisivanja Božje

\footnotetext{
${ }^{4}$ Usp. Tekst konačnog prijedloga XII. opće redovite Sinode biskupa. Dostupno na http://www.vatican.va/roman_curia/synod/documents/rc_synod_doc_20081025_elenco-prop-finali_it.html (3.9. 2018.)

${ }^{5}$ Ovdje uočavamo kako pojam nadahnuće može imati uzročnu i kvalitativnu vrijednost. Uzročna vrijednost govori o Bogu koji utječe na sastavljanje teksta, a kvalitativna vrijednost odnosi se na duhovnu narav tekstova, odnosno puninu Duha svetih tekstova. Usp. M. LIMBECK, La Sacra Srittura, 83.

${ }^{6}$ Usp. DRUGI VATIKANSKI KONCIL, Dogmatska konstitucija o božanskoj objavi $\gg$ Dei Verbum «, u: ISTI, Dokumenti, Zagreb, ${ }^{5}$ 1998. (= DV), br. 16.
}

${ }^{7}$ Usp. DV, br. 11. 
riječi kada su Božju riječ proživljavali pastiri i vođe naroda. ${ }^{8} \mathrm{U}$ tom smislu nadahnuće je u Starome zavjetu shvaćeno kao djelo Jahvina duha koji odabire određene ljude kako bi stanovitim gestama i izrazima (gestis et verbis) priopćili Božju volju. ${ }^{9}$ Tu pripada gesta Samuelova pomazanja Davida za kralja, što je znak Božje objave (1 Sam 16, 1s). Osobito su proroci promatrani kao oni koji su nadahnuti te govore u Jahvino ime, što u svojim govorima često i naglašavaju kad kažu riječ je Jahvina ili ovako govori Jahve. Kod njih se Jahvine riječi više gotovo ne razlikuju od njihovih riječi, čime je još istaknutija stvarnost nadahnuća. ${ }^{10}$

Novi zavjet neposredno govori o nadahnuću na dvama mjestima. Najprije 2 Tim 3, 16: »Sve Pismo, bogoduho, korisno je za poučavanje, uvjeravanje popravljanje, odgajanje u pravednosti «, i 2 Pt 1, 20-21: »Ponajprije znajte ovo: nijedno se proroštvo Pisma ne može tumačiti samovoljno, jer nikada proroštvo ne bî ljudskom voljom doneseno, nego su Duhom Svetim poneseni ljudi od Boga govorili.« Dar nadahnuća odnosi se dakle na autora koji je izabran i Bogom zahvaćen, odnosno nadahnut, što je vidljivo iz drugoga teksta, kao i na samo Pismo, kako pokazuje $2 \operatorname{Tim} 3,16 .{ }^{11}$

Za crkvene oce nadahnuće Pisma (koje se u početku odnosilo samo na Stari zavjet) bilo je po sebi očigledno i kao takvo prihvaćeno; nadahnuće se nije dovodilo u sumnju. Posve je drugo pitanje načina na koji su crkveni oci razumijevali nadahnuće. Crkveni oci nisu posvećivali mnogo pozornosti ljudskom autoru Svetoga pisma, do te mjere da Grgur Veliki podcrtava kako je Duh Sveti autor Svetoga pisma, a da je posve nevažno tko je bio ljudski pisac. ${ }^{12}$ Sve do Tome Akvinskoga nadahnuće se shvaćalo u značenju doslovnoga nadahnuća, prema kojemu bi se Bog, da bi izrazio svoju volju, poslužio ljudskim piscem kao nekim materijalnim sredstvom. U takvom shvaćanju Duh Sveti poslužio bi se prorocima kao što se flautist služi svojom flautom iz čega slijedi da Sveto pismo ima samo Boga za autora, odnosno

\footnotetext{
${ }^{8}$ Harrington navodi kako postoje tri oblika nadahnuća: 1) nadahnuće za djelovanje ili pastirsko nadahnuće koje pokreće pastire i vođe Božjeg naroda; 2) usmeno nadahnuće koje su imali proroci i apostoli kao govornici Božje riječi; 3) svetopisamsko nadahnuće koje je produženje i dopuna prvih dvaju. Usp. W. J. HARRINGTON, Uvod u Bibliju. Spomen objave, Zagreb, ${ }^{4} 1995 ., 50$.

${ }^{9}$ Mnogo šire o tome vidi: N. V. GAŠPAR, Teološki govor o Duhu Božjem. Od vječnosti do čovječnosti, Zagreb, 2012., 21-37., W. J. HARRINGTON, Uvod u Bibliju, 47-50.

${ }^{10}$ Usp. R. FISICHELLA, Ispirazione, u: R. LATOURELLE, R. FISICHELLA (ur.), Dizinoario di teologia fondamentale, Assisi, 1990., 621-622.

${ }^{11}$ U židovskom Svetom pismu nigdje se ne kaže da su nadahnuti spisi koji sadrže riječi proroka, iako se tvrdi da je Duh Božji duboko upleten u proročku djelatnost. Spisi su nadahnuti jer potječu od proroka. Dakle kao temeljnica vrijedi karizma proročkoga nadahnuća, iz čega se zaključuje nadahnuće svetih tekstova. Usp. D. HERCSIK, Elementi di teologia fondamentale, Bologna, 2006., 70s.

${ }^{12}$ Usp. W. J. HARRINGTON, Uvod u Bibliju, 47.
} 
da je ono božanski diktat. Pored takvoga razumijevanja nadahnuća, u prvim kršćanskim stoljećima pojavljuje se shvaćanje nadahnuća kao ekstaze i prosvjetljenja (iluminacije). ${ }^{13}$

S Tomom Akvinskim dolazi do prvoga sustavnoga nauka o nadahnuću. Studirajući temu proroštva, Toma dovodi u korelaciju objavu i nadahnuće. Nadahnuće je komplementarno objavi, po nadahnuću je prorok uzdignut po zahvatu Duha Svetoga na višu razinu spoznaje i tako može priopćiti i prenijeti božansku objavu. Primjenjujući aristotelovski sustav djelatne uzročnosti, koja može biti glavna i instrumentalna, skolastici su tvrdili da je Bog glavni uzročnik (causa principalis), a čovjek instrumentalni (causa instrumentalis). Time opisuju suradnju između Boga i hagiografa u nastajanju knjiga Svetoga pisma. Takva suradnja mogla bi se opisati slikom koja postoji između kovača i čekića dok se kuje željezo. Oba uzroka djeluju zajedno, ali ovaj put ne gube odlike svoje naravi. To znači da se Bog služi ljudskim piscem kao sredstvom, ali ne dokida njegovu slobodu, sposobnost, odgovornost, živost i inteligenciju. ${ }^{14}$

Tridentski koncil govori o svetopisamskim knjigama kao onima koje su izrečene/ izgovorene Duhom Svetim (Spiritus Sancto dictante), a ne više nadahnute Duhom Svetim kako je naučavao Firentinski koncil (Spiritus Sanctus inspirante) ${ }^{15}$, što je dovelo do kasnijih različitih interpretacija. Među njima se ističe Bañezovo tumačenje prema kojemu je Duh Sveti ne samo nadahnuo nego i diktirao svaku riječ (singula verba). Takvo poimanje zastupa tumačenje nadahnuća čija bi se svrha sastojala samo u očuvanju od pogrješaka. Riječ je o verbalnoj teoriji nadahnuća. Među prijeporne teorije tumačenja načina nadahnuća spada i Lessiusovo, gdje je nadahnuće poistovjećeno s potporom Duha Svetoga koji je trebao osigurati nepogrješivost svetoga pisca i svetih spisa, čime se protežira teorija o tzv. stvarnom ili realnom nadahnuću koje je ograničeno samo na sadržaj Svetoga pisma, ali ne i na njegove jezične izraze. Lessiusovu tumačenju pripada i teorija o naknadnom nadahnuću koja je držala da se ono sastoji u naknadnom crkvenom odobrenju knjige kao svete knjige. To tumačenje odbacio je već Prvi vatikanski sabor. ${ }^{16}$

${ }^{13}$ Usp. D. HERCSIK, Elementi di teologia fondamentale, 72-74.

${ }^{14}$ Usp. G. OCCHIPINTI, Nadahnuće u: L. PACOMIO, V. MANCUSO (ur.), Enciklopedijski teološki rječnik, Zagreb, 2009., 706.

${ }^{15}$ Usp. H. DENZINGER, P. HÜNERMANN (ur.) Zbirka sažetaka vjerovanja, definicija i izjava o vjeri i ćudoredu, Đakovo, 2002. (= DH), br. 1334., 1501. Firentisnki sabor prvi je ekumenski sabor koji se bavio pitanjem nadahnuća Svetoga pisma. Glede nauka o svetopisamskim tekstovima koji su Spiritus Sanctus inspirate, Koncil preuzima Origenov nauk koji ističe Boga kao autora obaju zavjeta te nadahnutost obaju zavjeta Duhom Svetim koji je uvodio proroke da zapišu ono što treba vjerovati. Usp. M. LIMBECK, La Sacra Srittura, 83.

${ }^{16}$ Usp. W. KERN, F. NIEMANN, Nauka o teološkoj spoznaji, Zagreb, 1994., 55.; G. OCCHIPINTI, Nadahnuće, 706.; R. FISICHELLA, Ispirazione, 621-622. 
Prije zaključaka Prvoga vatikanskoga sabora J. B. Franzelin vraća se Tominoj teoriji o glavnoj i instrumentalnoj uzročnosti prema kojoj je Bog autor svetih knjiga koji nadnaravno djeluje na ljudske pisce. Prema Franzelinu, Bog djeluje na razum i volju autora koji na taj način shvaća i zapisuje samo ono što Bog želi priopćiti. Shodno tomu nadahnuće nije shvaćeno kao spoznaja istine koju bi pisac mogao spoznati, nego kao puko zapisivanje istine. U tom procesu Bog je causa principalis, a pisac causa instrumentalis koji djeluje po Božjem zahvatu na ono što se tiče formalnoga dijela teksta te kao takav ostaje slobodan služiti se izražajnim formama koje su u skladu s njegovim vremenom. ${ }^{17}$ Prvi vatikanski sabor nije htio ulaziti u dublje tumačenje pojma nadahnuće, nego je samo naglasio da Crkva drži knjige obaju zavjeta

>Za svete i kanonske, ne zbog toga jer su sastavljene samom ljudskom marljivošću i (jer) ih je zatim potvrdila autoritetom; a niti zbog toga jer sadrže objavu bez zablude; nego zbog toga jer napisane po nadahnuću Duha Svetoga imaju Boga za pisca, i jer su kao takve predane samoj Crkvi ${ }_{1}{ }^{18}$

Time je Prvi vatikanski sabor preuzeo od Tridentskoga sabora tzv. načelo nadahnuća te je potvrdio da nadahnuće prethodi kanonu, ali da je prepoznato/priznato samo preko kanona. Drugim riječima, sveti spisi nisu nadahnuti zato što su kanonski, nego su kanonski jer su nadahnuti i kao takvi predani Crkvi. ${ }^{19}$

Nakon Prvoga vatikanskoga sabora vrijedi spomenuti još tri papinske enciklike koje su doticale pojam nadahnuća. Enciklika Providentissimus Deus iz 1893. godine opisuje nadahnuće analizom piščeve psihologije; enciklika Spiritus Paraclitus iz 1920. godine potvrđuje da utjecaj nadahnuća ne ometa vlastiti izraz piščeva genija i kulture, ali ga čuva od naučavanja zablude; te enciklika Divino afflante Spiritu iz 1943. godine koja stavlja naglasak na važnost doslovnoga smisla, a time i pravoga smisla koje je sveti pisac htio izraziti. ${ }^{20}$

\section{Odmak od restriktivnoga poimanja nadahnuća}

Drugi vatikanski sabor u dogmatskoj konstituciji o božanskoj objavi Dei Verbum donosi bitan pomak u razumijevanju nadahnuća. ${ }^{21}$ Nadahnuće se promatra u vrlo

\footnotetext{
${ }^{17}$ Usp. R. FISICHELLA, Ispirazione, 623.

${ }^{18} \mathrm{DH}$, br. 3006. Kurziv je naš.

${ }^{19}$ Usp. M. C. APARICIO VALLS, Ispirazione, 31., 35.

${ }^{20}$ Usp. G. OCCHIPINTI, Nadahnuće, 706.

${ }^{21}$ Usp. DV, br. 11. U ovome broju dogmatska konstitucija o božanskoj objavi sažima tradicionalni nauk o nadahnuću. To vidimo iz činjenice da se poziva na novozavjetne tekstove koji su bili predmetom rasprave o nadahnuću. Iz teksta DV 11 vidljivo je također da se koncilski oci pozivaju na Tridentski i Prvi vatikanski koncil te na enciklike Providentissimus Deus i Divino afflante Spiritu. Usp. D. HERCSIK, Elementi di teologia fondamentale, 67.
} 
širokom značenju povezujući ga s objavom i njezinim prenošenjem. Ti pomaci imaju se zahvaliti bibličarima i dogmatičarima koji su predložili nova moguća rješenja. Naslanjajući se na 2 Tim 3, 16, jasno se tvrdi da je nadahnuto cijelo Pismo, a ne da je samo očuvano od zabluda u stvarima vjere i morala, kako je predlagao utemeljitelj Katoličkoga instituta u Parizu (Institut Catholique de Paris) Maurice D'Hulst. ${ }^{22}$ Tekst dogmatske konstitucije o božanskoj objavi ne objašnjava kako se događa nadahnuće, nego samo ističe da Bog izabire ljude i da se služi njima kao pravim autorima.

Prvi značajan pomak Drugoga vatikanskoga sabora glede nadahnuća tiče se samoga ljudskoga autora teksta kojega se više ne promatra kao jednostavnoga, pasivnoga izvršitelja ili kao instrument u Božjim rukama. Svetoga pisca sada se promatra kao onoga kojega Bog izabire i koji kao istinski autor piše svoj tekst. Sveti pisac jest onaj koji studira, promišlja i istražuje spasenjsko iskustvo. On nosi težinu vlastite djelatnosti i originalnosti u kojoj izražava vlastitu osobnost. Bog ostaje autorom svetoga teksta (Urheber) jer on stvara povijest spasenja; on je na izvoru teksta, a sveti pisac nastoji izraziti njegovo djelovanje u logici same objave. Drugi važan pomak s Drugim vatikanskim saborom dogodio se u poimanju istine Pisma koju se više ne smatra kao nepostojanje pogrješaka u kontekstu nadahnuća, nego istinom koju je Bog želio da bude zapisana radi našega spasenja. Riječ je o istini koja je objavljena radi našega spasenja. Treći doprinos Sabora sastoji se u obnovljenom jedinstvu nadahnuća i objave. Djelo Duha Svetoga nalazi se na početku formiranja biblijskih tekstova, ono je prisutno pri prikupljanju građe, kao i prerađivanju ranijih spisa. Iako objava i nadahnuti tekst nisu identični, ipak su oboje djelo istoga Duha. ${ }^{23}$ Samo ako ostane povezano uz događaj objave, nadahnuće zadobiva svoj stvarni i puni smisao. Takvo jedinstvo otvara vrata teološkom proučavanju objave u kojoj je Krist punina, vrhunac i središte te proučavanju povijesnosti objave. Sveti pisac u korelaciji između objave i nadahnuća postaje svjestan da ga Bog izabire te se u intimnom odnosu s Bogom posve izručuje Bogu i prihvaća poslanje koje se sastoji u pisanom

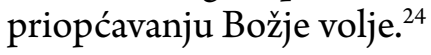

U vjernosti tradicionalnom nauku koji ima svoj korijen u Ivanu Zlatoustom nadahnuće se može razumjeti u analogiji s utjelovljenjem. Kao što je Riječ Božja postala tijelom po djelovanju Duha Svetoga u krilu Marije Djevice, tako se i Sveto pismo

\footnotetext{
${ }^{22}$ Usp. M. C. APARICIO VALLS, Ispirazione, 80.

${ }^{23}$ Usp. N. CAPIZZI, Dei Verbum. Storia/Commento/Recezione, Roma, 2015., 100. Objava zahvaća cijelo područje spoznaje, a nadahnuće se odnosi na praktični način priopćavanja objave. Usp. C. TOMIĆ, Pristup Bibliji, Zagreb, 1986., 45.

${ }^{24}$ Usp. R. FISICHELLA, Ispirazione, 624-625.
} 
rađa u krilu Crkve po djelovanju istoga Duha. ${ }^{25}$ Kao što je Riječ Božja zaista riječ ljudska - Bog je postao čovjekom, tako se analogijom utjelovljenja može kazati da Božja riječ postaje zaista ljudska jer je izgovaraju ljudi određenoga vremena za konkretno društvo, kako tvrdi Alonso-Schökel. ${ }^{26}$ Ta analogija govori nam da Bog dragovoljno dolazi uroniti u našu ljudskost. Bog po svome Sinu dolazi živjeti ljudski život, a Božje riječi imaju udjela u dinamici ljudskoga života. ${ }^{27}$

Time je naglašena pneumatološko-eklezijalna dimenzija nadahnuća. Nadahnuće nije individualni, karizmatski, nego crkveno-povijesni proces ukorijenjen u proces predaje, povijesti formi i redakcije. ${ }^{28}$ Nadahnuće Svetoga pisma djelo je Duha Svetoga i Sveto pismo jest za zajednicu, rođeno je unutar zajednice. To se osobito vidi kada Božja Riječ postaje zapisana: nadahnuće svetoga teksta nije osoban čin, nego se događa unutar zajednice koja vjerom prihvaća objavu i tako postaje Božjim narodom. Djelovanje Duha Svetoga ne ograničava se samo na finalni tekst Pisma, nego tome tekstu prethodi sveukupnost djela, iskustava, povijesnih okolnosti i život življen u zajednici ili u jednome narodu. Biblijski materijal često se dugo prenosio usmenom predajom prije nego što je bio zapisan. Ta činjenica znači da je Duh Sveti nadahnjivao um i srce svih koji su bili uključeni u razvoj biblijskoga materijala, kao i židovske i kršćanske zajednice iz kojih je potekao takav materijal. ${ }^{29}$ To nam pokazuje da konačni sveti tekst promatramo kao plod duhovnoga zrenja. ${ }^{30}$

Dakle prisutnost nadahnuća ne može se ograničiti samo na izolirane rečenice, nego se nadahnuta Božja riječ smješta unutar Božjega spasenjskoga plana jer je to mjesto Božjega djelovanja. ${ }^{31}$ Prije nego je sveti tekst zapisan, Bog se objavio riječima i djelima, prihvaćenim i interpretiranim najprije usmeno, a onda pisano. Prije nego što je došao do nas, sveti tekst prošao je prilično kompleksnu kompoziciju. Klasičan primjer za to nalazimo u Knjizi Izlaska: »Dođe Mojsije i kaza narodu sve riječi Jahvine i sve odredbe. A sav puk odgovori u jedan glas: 'Sve riječi što ih Jahve reče, vršit ćemo.' Tada Mojsije popiše sve riječi Jahvine. A ujutro podrani te podigne žrtvenik na podnožju brda i dvanaest stupova za dvanaest plemena Izraelovih.«(Izl 24, 3-4) Ovdje je posve jasan proces koji prethodi zapisivanju. Na početku se nalazi Riječ

${ }^{25}$ Usp. DV, br. 13.

${ }^{26}$ Navedeno prema M. C. APARICIO VALLS, Ispirazione, 38.

${ }^{27}$ Usp. KATOLIČKA BISKUPSKA KONFERENCIJA ENGLESKE I WALESA, KATOLIČKA BISKUPSKA KONFERENCIJA ŠKOTSKE, Sveto pismo - Božji dar. Učiteljski dokument Biskupskih konferencija Engleske i Walesa, i Škotske, Zagreb, 2006., br. 16.

${ }^{28}$ Usp. J. RATZINGER - BENEDIKT XVI., Dogma i navještaj, Zagreb, 2011., 20.

${ }^{29}$ Usp. KATOLIČKA BISKUPSKA KONFERENCIJA ENGLESKE I WALESA, KATOLIČKA BISKUPSKA KONFERENCIJA ŠKOTSKE, Sveto pismo - Božji dar, br. 15.

${ }^{30}$ Usp. M. C. APARICIO VALLS, Ispirazione, 17-18.

${ }^{31}$ Usp. isto, 40. 
Božja upućena Mojsiju, potom je priopćena narodu koji je prihvaća kao Božju riječ i na kraju kad je prihvaćena postaje zapisana. ${ }^{32}$ Taj proces koji se artikulira u trima koracima jasno ocrtava da se nadahnuće ne odnosi samo na finalni tekst. Drugim riječima, »nadahnuće ne obuhvaća izgovaranje ili mehaničko zapisivanje riječi primljenih odozgor, nego sastavljanje knjige sa svim pothvatima i ljudskim zalaganjem koje takva zadaća iziskuje ${ }^{33}$. To znači da su bili nadahnuti svi oni koji su doprinijeli nastanku Biblije. Svatko je od njih imao udio na karizmi - u većoj ili manjoj mjeri - u kojoj surađuje u nastajanju knjige. To pokazuje da je nadahnuće trajno i dinamično svojstvo koje se očituje u tome što riječ Božja budi odgovor vjernika. ${ }^{34}$

Već smo spomenuli da je Sveto pismo za zajednicu, oblikuje se unutar zajednice i zajednica ga prihvaća. U tom kontekstu vrijedno je spomenuti teoriju nadahnuća koju donosi Karl Rahner, koja je imala raznoliku recepciju. Mogli bismo je nazvati eklezijalnom teorijom jer polazi od utemeljenja Crkve te ju povezuje s nadahnućem Pisma. ${ }^{35}$ Njegova teorija svakako se udaljava od restriktivnoga shvaćanja nadahnuća. Rahnerova polazna točka jest da Bog apsolutno i bezuvjetno želi Crkvu. On to opravdava pojmom formalne predefinicije koja znači da Bog unaprijed određuje spasenjski čin koji čovjek treba ispuniti te mu onda daje i potrebnu milost i sredstva da ga ispuni. Na taj način njemački teolog tumači postanak Crkve. Jedan od konstitutivnih elemenata Crkve jest Sveto pismo koje ostvaruje ono što je Pracrkva vjerovala i u što je vjerujući sebe potvrdila. Dakle mjerilo i norma svih daljnjih stoljeća povijesti Crkve jest Pracrkva, osobito po Pismu jer je po Pismu moguće saznati tu vjeru Pracrkve. Pracrkva je u Pismu napismeno očitovala svoju vjeru. Slijedeći takvo razmišljanje, Rahner zastupa tezu da Bog hoće Crkvu i po Kristu je ustanovljuje s njezinim konstitutivnim elementima, a time jednako tako hoće i

\footnotetext{
${ }^{32}$ Usp. isto, 19. Nadahnuće možemo shvatiti u užem smislu. Tada se ono odnosi samo na proces sastavljanja svetoga teksta. A ako ga razumijemo u širem smislu, onda ono pretpostavlja i prihvaćanje toga teksta kao Božje riječi. Uvijek je dakle prisutna djelatnost Duha Svetoga. Usp. isto, 20.

${ }^{33}$ W. J. HARRINGTON, Uvod u Bibliju, 85.

${ }^{34}$ Usp. isto, 95.

${ }^{35}$ U svemu što slijedi o toj temi referiramo se na: W. KERN, F. NIEMANN, Nauka o teološkoj spoznaji, 56-61. Vrijedi vidjeti i Harringotovo tumačenje Rahnerove teorije u: W. J. HARRINGTON, Uvod u Bibliju, 57-65. Osim Rahnerove teorije nadahnuća u katoličkoj teologiji poznata je i psihološka teorija nadahnuća koju zastupa Pierre Benoît čineći od ljudske psihe locus nadahnuća stavljajući tako naglasak na pojedine biblijske autore. Socijalna ili društvena teorija nadahnuća dokida psihološku naglašavajući međuovisnost između biblijskoga autora i zajednice, gotovo svodeći autora na anonimnoga pisca. U novije vrijeme na protestantskoj strani s obzirom na nadahnuće pojavila se teorija konkomitancije kojom se naznačava uloga Duha Svetoga u sastavljanju svetih knjiga. Usp. D. HERCSIK, Elementi di teologia fondamentale, 84-87. O protestantskom poimanju nadahnuća i istine Svetoga pisma vidi: D. TURALIJA, Nadahnuće i istinitost Svetoga pisma - pozitivni privilegij Biblije, u: Riječki teološki časopis 25(2017.)2, 256-259.
} 
Pismo kojemu je on na taj način nadahnjujući pisac i njegov uzročnik. To implicira da je nadahniteljsko Božje autorstvo nutarnji element nastajanja Pracrkve upravo kao Crkve, odnosno nadahnuće Pisma samo je drugi vid Božjega čina kojim stvara i ustanovljuje Crkvu. Jednaku teoriju Rahner primjenjuje i na teologiju sakramenata. Takva Rahnerova teorija upućuje na određene zaključke. Riječ je, prije svega, o odnosu nadahnuća i kanona koji smo već ocrtali. Bilo bi besmisleno da postoji neka nadahnuta knjiga koja nije u kanonu. Bog je autor Svetoga pisma, ali i čovjek je stvarni književni pisac Svetoga pisma. Božje autorstvo shvaća se tako da on najprije omogućuje, a onda i zahtijeva pravo čovjekovo autorstvo. Nadahnuće prestaje kada je dovršeno ustanovljenje Crkve. Svijest o tome da je netko nadahnut, prema Rahneru, sastoji se u tome da pisac zna da pripada Crkvi koja je upravo u trenutku ustanovljenja. Svijest o nadahnuću ne mora značiti da se npr. Pavao dok piše neku od svojih poslanica osjećao na poseban način prosvijetljen Duhom Svetim da piše jedan kanonski tekst. Na pitanje kako Crkva prepoznaje nadahnuće Pisma Rahner odgovara da Crkva tek kasnije spoznaje je li određeni spis iz apostolskoga vremena u skladu s njezinom naravi ili nije. Crkva u svojoj cjelini prepoznaje Pismo kao izvorni izraz svoje vjere.

\section{Papinska biblijska komisija o nadahnuću Svetoga pisma}

Doprinos dokumenta Nadahnuće i istina Svetoga pisma. Riječ koja dolazi od Boga i govori o Bogu da spasi svijet Papinske biblijske komisije iz 2014. godine ${ }^{36}$ sastoji se u tome da upozorava na šire razumijevanje nadahnuća koje se ne može ograničiti samo na usko semantičko polje. Drugim riječima, ne možemo tumačiti nadahnuće polazeći samo od dvaju novozavjetnih tekstova koji spominju nadahnuće (2 Tim 3, 16 i 2 Pt 1 , 20-21). Time se nadahnuće dovodi u vezu s objavom, što predstavlja kontinuitet s naukom Dei verbum, br. 11. Široki pojam objave i uži pojam objave koji se vidi u njezinoj pisanoj potvrdi, dakle u nadahnuću, promatraju se kao jedinstven proces. ${ }^{37}$

\footnotetext{
${ }^{36}$ PAPINSKA BIBLIJSKA KOMISIJA, Nadahnuće i istina Svetoga pisma. Riječ koja dolazi od Boga $i$ govori o Bogu da spasi svijet, Zagreb, 2016. O povijesti nastanka toga dokumenta i njegovu tumačenju vidi: A. POPOVIĆ, Nadahnuće i istina Svetoga pisma prema dokumentu Papinske biblijske komisije, u: Bogoslovska smotra 85(2015.)4, 1049-1076. Ovdje autor izvrsno uviđa da dokument Papinske biblijske komisije ne stavlja u prvi plan nadahnuće svetopisamskih knjiga, nego božansko podrijetlo poruke što je utemeljeno na nauku prethodnih dokumenata koji stavljaju naglasak na Boga kao autora i nadahnitelja ljudskih pisaca. Usp. isto, 1059., bilj. 18.

${ }^{37}$ Usp. PAPINSKA BIBLIJSKA KOMISIJA, Nadahnuće i istina Svetoga pisma, br. 7. Crkveni dokumenti Dei verbum i Verbum Domini razlikuju objavu i nadahnuće kao dva različita božanska djelovanja. Po objavi Bog priopćuje tko je i koje je otajstvo njegove volje, a nadahnuće se javlja kao djelovanje po kojem Bog izabire i osposobljava određene ljude da u pisanom obliku priopće Božju volju. Karizma nadahnuća odnosi se više na praktični način priopćavanja Božje volje. Usp. isto, br. 7; C. TOMIĆ, Pristup Bibliji, 44.
} 
Nadahnuće se tumači pokazivanjem kako biblijske knjige imaju svoje podrijetlo od Boga, što znači da su nadahnute, a što je vidljivo iz odnosa koji se na različite načine ostvaruje između Boga i ljudskih autora. ${ }^{38}$ Odnos između pojedinih pisaca i Boga u Starome zavjetu događa se na mnogostruke načine: taj odnos i više je nego očit između Boga i Mojsija te Boga i proroka. U psalmima se taj odnos manifestira tako što čovjek govori Bogu, ali u njegovoj nazočnosti. U mudrosnim knjigama ljudi govore ljudima, ali ukorijenjeni u vjeru u Boga izraelskoga naroda. Obilježje pak spisa Novoga zavjeta jest da očituju odnos svojih autora s Bogom samo po Isusovoj osobi. Pavao u svojim poslanicama potvrđuje božansko podrijetlo Pisma; Poslanica Hebrejima govori o Bogu koji govoraše ocima po prorocima. ${ }^{39}$ Odnos s Bogom za novozavjetne pisce ovisi o odnosu s Isusom bilo povijesnim bilo postpashalnim, kako je slučaj sa svetim Pavlom, ili pak o svjedocima koji su slušali Gospodinov navještaj. ${ }^{40}$ Iz uvida u biblijske spise koji svjedoče o povezanosti Boga i ljudskoga autora mogli bismo nadahnuće razumjeti kao poseban odnos s Bogom po kojem on dariva ljudskomu piscu da kaže ono što Bog želi priopćiti ljudima.

U slučaju evanđelja i apostolskih spisa dva su presudna elementa za podrijetlo od Boga: $a)$ osobni odnos vjere s $b$ ) izvorom po kojem se Bog objavljuje. Drugim riječima, određeni biblijski spis dolazi od Boga po živoj vjeri njegova pisca u Boga i po povezanosti toga pisca s određenim oblikom božanske objave. To možemo vidjeti osobito u evanđeljima gdje je temeljan osobni odnos s Gospodinom Isusom življen vjerom u njegovu osobu - upravo je to temelj nadahnuća koje osposobljava apostole da priopćuju usmeno ili pisano Isusovu poruku koja je Riječ Božja. Dakle nije presudno priopćavanje riječi koje je Isus doslovno izgovorio, nego navještaj njegova evanđelja. Konkretni način podrijetla od Boga jest različit (zakonski tekstovi, viđenja, mudrosne knjige, proročanstva), no ono što je neprekinuto prisutno jest vjera ljudskoga pisca u Boga i njegova poslušnost različitim oblicima božanske objave. ${ }^{41}$ Temeljna je Božja komunikacija i vjerničko prihvaćanje sadržaja koje je potom praćeno božanskom asistencijom za zapisivanje. ${ }^{42}$

Ukratko rečeno, obilježja nadahnuća koja proizlaze iz svetopisamskih tekstova u kojima se svjedoči njihovo podrijetlo od Boga mogu se promatrati kroz tri točke:

\footnotetext{
${ }^{38}$ Usp. PAPINSKA BIBLIJSKA KOMISIJA, Nadahnuće i istina Svetoga pisma, br. 6. Upravo je to tema prvoga dijela dokumenta PBK Nadahnuće i istina Svetoga pisma koji u izabranim spisima Staroga i Novoga zavjeta pokazuje usku povezanost između Boga i svetoga pisca.

${ }^{39}$ Usp. isto. Dekalog je jedini tekst za koji se kaže da ga je sam Bog zapisao kako je razvidno iz ovih tekstova: Izl 24, 12; 31, 18; 32, 16; 34, 1.28; Pnz 4, 13; 9, 10; 10, 4. Usp. isto, br. 12.

${ }^{40}$ Usp. isto, br. 51.

${ }^{41}$ Usp. isto, br. 8-9.

${ }^{42}$ Usp. isto, br. 51.
} 
a) osobni odnos s Bogom (vjera u Boga) svetoga pisca, b) prihvaćanje različitih načina Božje objave (stvaranje, povijest, punina objave u Kristu), c) činjenica da se u ekonomiji Božje objave osobni odnos s Bogom i način objave mijenjaju ovisno o fazama i okolnostima objave. Iz toga se može zaključiti da je nadahnuće analogno isto za sve pisce biblijskih knjiga, ali je raznovrsno zbog ekonomije božanske objave koja svoj vrhunac ima u Kristu. ${ }^{43}$ Ovako narav nadahnuća te odnos s kanonom i istinom Svetoga pisma sažima dokument Papinske biblijske komisije:

$\gg$ Nadahnuće Svetoga pisma odnosi se na svaki od tekstova koji čine Pismo kao i na cjelinu kanona. Ustvrditi da je biblijska knjiga nadahnuta znači priznati da je ona specifičan i privilegiran prenositelj Božje objave ljudima, i da su njezini ljudski pisci bili potaknuti Duhom da izreknu istine vjere u tekstu koji ima svoje povijesno mjesto i kojega je zajednica vjernika prihvatila kao normativan. Ustvrditi da Pismo, u svojoj cjelini, jest nadahnuto, znači priznati da ono oblikuje kanon, to jest cjelinu spisa normativnih za vjeru, koji su prihvaćeni u Crkvi. Kao takva Biblija je mjesto objave nenadmašne istine koja se poistovjećuje s osobom Isusa Krista, koji svojim riječima i svojim djelima 'ispunjava' i 'usavršava’ tradicije Staroga zavjeta, objavljujući Oca u potpunosti. « ${ }^{44}$

\section{Poimanje istine Svetoga pisma do Drugoga vatikanskoga sabora}

Već smo istaknuli kako postoji nerazdvojiva unutarnja veza između nadahnuća i istine Svetoga pisma. Proučavanje nadahnuća dovodi do boljega razumijevanja istine koja je sadržana u Svetome pismu.$^{45} \mathrm{Da}$ bismo mogli govoriti o istini Svetoga pisma, potrebno je najprije odrediti terminus ad quem, tj. ono prema čemu idemo. Nužno je nedvojbeno precizirati koju istinu tražimo i o kojoj je istini riječ u Svetome pismu.

$\mathrm{U}$ intelektualističkom grčkom poimanju pod istinom se obično podrazumijeva $\gg$ misao, riječ koja je u skladu sa stvarnošću, ili, također, i sama stvarnost koja se otkriva, koja je jasna, očita duhu (istinit, a-lèthēs = ne-skriven) $[. .$.$] Biblijski je$ pojam istine drugačiji, jer se temelji na religioznom iskustvu, na iskustvu susreta s Bogom $\ll{ }^{46}$ I u samom Svetome pismu pojam istine doživio je određeni razvoj. Stari zavjet izražava istinu pojmom emet, istina je dakle svojstvo onoga što je čvrsto, stameno, na što se može osloniti. Biblijska istina povezana je s Božjim zahva-

$\overline{{ }^{43} \text { Usp. isto, br. } 52 ., 142 .}$

${ }^{44}$ Isto, br. 57. Kurziv je naš.

${ }^{45}$ Usp. VD, br. 19. Usp. G. L. MÜLLER, Predgovor, u: PAPINSKA BIBLIJSKA KOMISIJA, Nadahnuće i istina Svetoga pisma, 5.

${ }^{46}$ I. DE LA POTTERIE, Istina, u: X. LÉON-DUFOUR (ur.), Rječnik biblijske teologije, Zagreb, ${ }^{4} 1993 ., 338$. 
tima u povijesti spasenja i izražava se Božjom vjernošću svojim obećanjima. Cijela povijest Staroga zavjeta neodvojivo naglašava vezu između istine i vjernosti. Ljudi istine jesu povjerljivi, bogobojazni, vjerni i pravedni. U Novome zavjetu, osobito u Pavlovim poslanicama, osim poimanja istine u smislu moralnosti i pravednosti, uviđamo da je Božja istina oznaka za njegovu vjernost svojim obećanjima, kao i u Starom zavjetu. Prihvaćanje istine evanđelja događa se po vjeri. Doći do spoznaje istine u pavlovskim poslanicama postaje sinonim za prionuti uz evanđelje, prigrliti kršćanstvo jer su kršćani oni koji su upoznali istinu (1 Tim 4,3). Pavao svoju službu vidi upravo u objavljivanju istine koja je Kristova istina (2 Kor 4, 1). U evanđeljima susrećemo da je Isus Krist istina (Iv 14, 6). On šalje Duha istine (Iv 14, 7). Vjernik se mora truditi biti prijatelj istine jer istina oslobađa (Iv 8, 32). Hoditi u istini znači hoditi u zapovijedi ljubavi u kojoj Isus sažima sav Zakon i Proroke. U kršćanskome smislu istina je istina evanđelja, objavljena Očeva riječ u osobi Isusa Krista. Crkva, koju je Krist želio i utemeljio, postaje stup i uporište istine $(1 \operatorname{Tim} 3,15) \cdot{ }^{47} \mathrm{Kao}$ verbum abbreviatum Isus je Spasitelj, u njemu je Bog objavio sve ono što je radi našega spasenja, on jest naše spasenje, u njemu je ono sažeto: od planiranja do ostvarenja. Kao Riječ Božja Isus u sebi sažima svu istinu, rasprostranjenu i progresivno raslu u Svetome pismu, a to je istina koja se tiče našega spasenja i plana toga spasenja. U njemu je zablistala istina spasenja koju trebamo tražiti u Svetome pismu. On je jedincata i jedinstvena uosobljena istina Svetoga pisma i kao takav ostaje temelj i kriterij svih istina. Isus Krist jest veritas abbreviatum, koja zbog svoga sadržaja ostaje punina i vrhunac. Ako od njegove punine svi mi primismo (Iv 1, 16), onda se ta punina razlijeva i po cijelome Svetome pismu. Zbog toga cijelo Sveto pismo, kao $\mathrm{i}$ istinu Svetoga pisma trebamo tumačiti i čitati u kristološkom ključu jer je Krist središte i punina povijesti spasenja. U njemu nam je zasjala konačna istina o Bogu i čovjeku..$^{48}$ Istina Svetoga pisma ne sastoji se u istinama različitih propozicija, nego u središnjem objektu objave - Kristu kojemu su usmjere sve božanske istine. ${ }^{49}$ No trebamo imati na umu da je istina koja se nalazi u Svetome pismu univerzalna, što implicira da je namijenjena svima jer Bog »hoće da se svi ljudi spase i dođu do spoznanja istine $\ll(1 \operatorname{Tim} 2,4)$.

\footnotetext{
${ }^{47}$ Usp. isto, 338-345.; I. DE LA POTTERIE, Verità, u: R. LATOURELLE, R. FISICHELLA (ur.), Dizionario di teologia fondamentale, 1449-1455.; PAPINSKA BIBLIJSKA KOMISIJA, Nadahnuće i istina Svetoga pisma, br. 64.

${ }^{48}$ Usp. DV, br. 2.

${ }^{49}$ Usp. M. C. APARICIO VALLS, Ispirazione, 93. U tom kontekstu vrijedi uputiti i na govor o hijerarhiji istina jer je različita njihova povezanost s temeljem kršćanske vjere. Time se želi reći da postoji mnoštvo kršćanskih istina, ali da nemaju sve jednaku važnost. Neke su središnje jer su one obzor i ključ interpretacije drugih istina. Usp. DRUGI VATIKANSKI KONCIL, Dekret o ekumenizmu »Unitatis redintegratio «, u: ISTI, Dokumenti, Zagreb, ${ }^{5}$ 1998. (= UR), br. 11.
} 
Ta kratko ocrtana biblijska perspektiva istine nedvojbeno pokazuje o kakvoj je istini riječ u Svetome pismu, što će posve jasno istaknuti dogmatska konstitucija o božanskoj objavi Drugoga vatikanskoga sabora. Povijest teologije pokazuje da su se teolozi nakon Augustina ${ }^{50}$ najprije služili pojmom nezabludivosti Svetoga pisma. ${ }^{51}$ Ako se taj termin uzme u apsolutnom smislu, onda to implicira da u Bibliji ne može biti nikakve pogrješke, tako da se sve više počelo govoriti o odsutnosti pogrješaka umjesto o istini Svetoga pisma. Ovdje nije riječ tek o pukoj jezičnoj promjeni, nego o promjeni mentaliteta. Enciklika Providentissimus Deus dovodi u vezu nadahnuće i odsutnost pogrješke u Svetome pismu tvrdeći da je nadahnuto cijelo Sveto pismo i kao takvo je nepogrješivo. ${ }^{52}$ Važno pojašnjenje te papinske enciklike sastoji se $u$ tome da ne može doći do sukoba između biblijske i znanstvene istine, zato što je riječ o različitim točkama i razinama gledanja, jer istina koju tražimo u Svetome pismu nije prirodno-znanstvena, nego istina koja se tiče našega spasenja. ${ }^{53}$ Ako se želi tražiti znanstvenu istinu u Svetome pismu, brzo će se doći do zaključka da je ono puno pogrješaka. Svrha nadahnuća tiče se spasenja, a ne znanstvene ili precizno utvrđene povijesne spoznaje. Dakle Bog nije nadahnuo svete pisce kako bi govorili o tome kako je Herod imao službu tetrarha ili da bi im priopćio da se Isus rodio za vrijeme cara Augusta ili pak da bi ih uputio na neke geografske činjenice, nego se poslužio njima da kao istinski autori, uključujući svoju spoznaju, inteligenciju i kulturni ambijent, pa i svoje ograničenosti, zapišu onu istinu koju Bog hoće radi našega spasenja. Duh Sveti nije poučavao hagiografe o suptilnoj povijesnoj ili znanstvenoj strukturi koja ne služi spasenju. ${ }^{54}$

\section{Odmak od sine errore Svetoga pisma}

Sve do pred Drugi vatikanski sabor govorilo se o nepogrješivosti, odnosno o odsutnosti pogrješaka (sine errore) u Svetome pismu umjesto o istini. Razvojem povijesno-kritičke metode i primjene iste na Sveto pismo te egzaktnih znanosti i arheologije i jačanjem filozofsko-racionalnoga poimanja istine, kao i u slučaju Galilea Galileija, moralo se priznati kako u Bibliji nije sve izrečeno sukladno zahtjevima

\footnotetext{
${ }^{50}$ Augustin, u borbi protiv manihejaca, produbljuje temu istine Svetoga pisma protežući ju na cijelo Sveto pismo precizirajući da je istina koja se nalazi u Svetome pismu istina za naše spasenje. Ta njegova ideja bit će ponovno preuzeta tijekom XIX. i XX. stoljeća. Usp. M. C. APARICIO VALLS, Ispirazione, 75-76.

${ }^{51}$ Pojam nezabludivost nije se nikada pojavio u nekom koncilskom tekstu, iako se nalazi u nekim papinskim enciklikama i pripremnim dokumentima Drugoga vatikanskoga sabora. Usp. D. HERCSIK, Elementi di teologia fondamentale, 83.

${ }^{52}$ Usp. DH, br. 3291-3292.

${ }^{53}$ Usp. DH, br. 3287-3288.

${ }^{54}$ Usp. J. FUĆAK, Istinitost Svetoga pisma, u: Bogoslovska smotra 37(1967.)1-2, 44-52., ovdje 46.
} 
suvremenih prirodnih znanosti. ${ }^{55} \mathrm{~S}$ Drugim vatikanskim saborom dolazi do obrata u govoru o istini koja je sadržana u Svetome pismu. Toj promjeni jezika i mentaliteta doprinijela su teološka promišljanja koja su prethodila Saboru. U tom pothvatu posebno su se istaknuli P. Grelot i P. Benoît koji promatraju istinu Svetoga pisma iz posve druge perspektive u odnosu na onu koja je vladala dotad. Benoît uviđa kako u Svetome pismu postoje različite istine: geografske, povijesne, istine koje se tiču službe nekih biblijskih ličnosti i dr. Odlučujući trenutak sastoji se u tome da francuski bibličar vidi kako je u Bibliji sve usmjereno spasenju. Sveto pismo nije zbirka istina, nego knjiga naroda koji korača prema punini spasenja. Povijest u kojoj se događa objava treba interpretirati u njezinu spasenjskom značenju. Istina koju nam Bog nudi nije nešto očigledno i neposredno, nego se sastoji u progresivnom otkrivanju u povezanosti s Božjom objavom i spoznajom koju čovjek ima o sebi. ${ }^{56}$

Prema Grelotu, govor o nepogrješivosti Pisma predstavlja u negativnom svjetlu njegov pozitivni privilegij koji kao Božja riječ participira na samoj Božjoj istini. Grelot podcrtava da je istina Svetoga pisma jednakoga reda kao i istina objave. U otkrivanju istine Pisma potrebno je zajedno držati objavu i njezin progresivni karakter. ${ }^{57}$

Dei Verbum u broju 11 naučava o istini koju je Bog htio da radi našega spasenja bude zapisana u Svetome pismu. ${ }^{58}$ Time se predstavlja nadahnuće povezano s objavom čija je svrha spasenje. Ta se istina ne sastoji u apsolutnoj odsutnosti pogrješaka pojedinih prijedloga, nego u tome da je cijelo Sveto pismo usmjereno objavi Božjega spasenjskoga plana. Istina Svetoga pisma ima objaviteljsku, a ne povijesnu, prirodno-znanstvenu ili matematičku vrijednost. Stoga se ta istina može shvatiti i primjereno razumjeti samo u obzoru vjere. I vjera i istina koju razumijemo vjerom nisu plod našega otkrića, nego su dar. Ne otkrivamo mi istinu, nego se istina otkriva nama, a mi ju vjerom gledamo i prihvaćamo. Istina našega spasenja dolazi k nama u susret, stoji i kuca na našim vratima (Otk 3, 20). Naš doprinos sastoji se tek u raspoloživosti srca i uma da tu istinu prepoznamo i prihvatimo kao istinu za naše spasenje: vjerom, molitvom, meditacijom i kontemplacijom. Kao posljedica toga na nas spada akcija, djelovanje, koje se sastoji u svjedočenju za istinu (Iv 5, 33).

\footnotetext{
${ }^{55}$ Usp. PAPINSKA BIBLIJSKA KOMISIJA, Nadahnuće i istina Svetoga pisma, br. 63.

${ }^{56}$ Usp. M. C. APARICIO VALLS, Ispirazione, 85-86.

${ }^{57}$ Usp. isto, 86.

${ }^{58}$ Usp. M. LIMBECK, La Sacra Scrittura, 88. Terminus tehnicus »veritas salutaris « napušten je u korist deskriptivnoga i dužega pojašnjenja o kakvoj je istini riječ jer je mogao značiti da se nepogrješivost Pisma odnosi samo na veritas salutaris kao materijalni objekt nepogrješivosti, dakle samo na neke dijelove Svetoga pisma, npr. one koje se tiču vjere i morala, a ne na cijelo Sveto pismo. Usp. isto; PAPINSKA BIBLIJSKA KOMISIJA, Nadahnuće i istina Svetoga pisma, br. 63.
} 
Iz analize DV 11 proizlazi da u Pismu treba tražiti ono što pripada sadržaju objave, a spasenje je bitni sadržaj objave, ono je to u osobi Isusa Krista, vrhuncu i punini objave. Povijesno gledano, istina spasenja jednako se - kao i cijela objava - razvija progresivno: od obećanja u trećem poglavlju Knjige Postanka, preko utjelovljenja do pashalnoga misterija.

Teološki gledano, istinu Svetoga pisma ne možemo shvatiti kao materijalni objekt koji bi se mogao suprotstaviti drugim istinama u Pismu kao da bi Pismo bilo podijeljeno na dio koji je nadahnut i lišen pogrješaka i na dio koji nije nadahnut te je podložan pogrješkama. Istina koja je zapisana u Svetome pismu radi našega spasenja jest formalni objekt pod kojim je Pismo sastavljeno i pod kojim nam je dano. ${ }^{59}$ Biblija je sveto pismo upravo zato što u njoj Bog svjedoči istinu koju mi ljudi nužno trebamo za spasenje. ${ }^{60}$ Istina Pisma $\gg$ ne sastoji se toliko u činjenici da su u njegovim pojedinim dijelovima odsutne pogreške, nego u činjenici da po Pismu Bog očituje svome narodu svoju vjernost privodeći ga zajedništvu ljubavi sa sobom «. ${ }^{61}$ Iz toga razloga i zbog svrhe i plana Božjega priopćavanja istine spasenja ne bismo trebali očekivati potpunu točnost biblijskih podataka glede onoga što se ne tiče istine spasenja, prije svega se to odnosi na povijesne i znanstvene istine. ${ }^{62}$

\section{Papinska biblijska komisija o istini Svetoga pisma}

Papinska biblijska komisija u dokumentu Nadahnuće i istina Svetoga pisma. Riječ koja dolazi od Boga i govori o Bogu da spasi svijet u svom drugom dijelu uglavnom sažima nauk Drugoga vatikanskoga sabora o istini Svetoga pisma, što svoj najvažniji izraz ima u broju 11 dogmatske konstitucije o božanskoj objavi Dei Verbum. Mi smo taj obzor ocrtali u glavnim linijama u prethodnim poglavljima. Ukratko, možemo naglasiti kako je i taj dokument posvemašnjega uvjerenja da istina koja je u središtu objave i u središtu Svetoga pisma jest istina koja se odnosi na Boga i na spasenje čovjeka. Sveto pismo nije zbirka koja donosi točne informacije iz različitih područja ljudskoga znanja, nego istinu u kojoj Bog objavljuje sebe i svoj naum spasenja ljudi. Na to jasno upozorava i Prva Petrova poslanica koja govori o spasenju

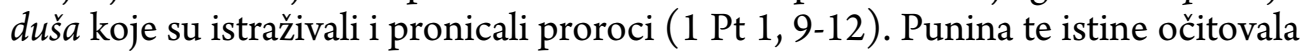

\footnotetext{
${ }^{59}$ Usp. H. WALDENFELS, Kontekstualna fundamentalna teologija, Đakovo, 1995., 673-674. Već je Augustin, kako navodi enciklika Providentissumus Deus, govorio o vrsti istine koja se nalazi u Svetome pismu. Ta istina ne tiče se vidljivih stvari, nego ima važnost za vječno spasenje. Usp. $\mathrm{DH}$, br. 3288.

${ }^{60}$ Usp. M. LIMBECK, La Sacra Scrittura, 88-89.

${ }^{61}$ D. HERCSIK, Elementi di teologia fondamentale, 84.

${ }^{62}$ Usp. KATOLIČKA BISKUPSKA KONFERENCIJA ENGLESKE I WALESA, KATOLIČKA BISKUPSKA KONFERENCIJA ŠKOTSKE, Sveto pismo - Božji dar, br. 14.
} 
se u Kristu i po njemu. Istina biblijskih spisa odnosi se dakle na ono što ti spisi kažu o Bogu i o Božjem planu spasenja za čovjeka. To je specifičnost biblijske istine.

Dokument Papinske biblijske komisije izabranim svetopisamskim tekstovima konkretno upozorava na tu Božju spasenjsku istinu koja je prisutna u cijelome Svetom pismu, od Knjige Postanka do Otkrivenja. Ona je izrečena u više oblika i na različite načine. Time se pokazuje da je punina spasenjske istine koju je donio Krist pripravljana i posvjedočena u spisima Staroga zavjeta. ${ }^{63}$ Tako se npr. u Post $1,1-2$, 4a ne želi precizno opisati kako je i kada nastao svijet, nego zašto i s kojim ciljem je on takav kakav jest - ili bi trebao biti - i tko ga je stvorio takvim. Stvarajući čovjeka na sliku Božju, Bog očituje svoju temeljnu spasenjsku volju. Jednako tako povijesne knjige koje prikazuju Izraelovu povijest jasno pokazuju da nije riječ o historiografiji ili kronici, nego svjedoče o Božjoj spasenjskoj volji i brizi za čovjeka. ${ }^{64}$

Na koji način novozavjetni spisi svjedoče o Riječi koja govori o Bogu da spasi svijet (drugi dio podnaslova dokumenta), odnosno o istini, Papinska biblijska komisija pokazuje izabranim evanđeoskim tekstovima, Pavlovim poslanicama i knjigom Otkrivenja. ${ }^{65}$ Novozavjetni spisi pomažu čovjeku susresti Istinu, odnosno Krista i istinu koju on objavljuje o Bogu i ljudskom spasenju. Komisija posvećuje dostatan prostor Pavlovim poslanicama u kojima Apostol daje svjedočanstvo o Bogu i ljudskom spasenju u četirima koracima: a) Pavao poznaje objavu iz vlastitoga poziva i predaje; b) Bog se objavljuje u raspetom i uskrslom Kristu; $c$ ) spasenje se prima i živi u Crkvi; d) punina spasenja sadržana je u uskrsnuću s Kristom. U knjizi Otkrivenja nalazi se istina koju je Bog darovao Isusu Kristu, a odnosi se na Božji stvaralački i spasenjski plan. Spisi Staroga i Novoga zavjeta pokazuju istinu koja nalazi puni izraz u osobi Isusa Krista. To nam potvrđuje da, ako se Sveto pismo čita u kristološkom hermeneutskom ključu i pod vidom istine koju je Bog htio da bude zapisana radi našega spasenja, onda u njemu nema kontradikcija ni pogrješaka. No primijenimo li na njega metode prirodnih i drugih znanosti, osim što se gubi iz vida istina našega spasenja, ono postaje beskorisno i apsurdno. To otvara vrata prema hermeneutici Svetoga pisma, odnosno prodornom upozorenju da je samo pristup koji vodi računa o kanonskoj sveukupnosti Pisma sposoban otkriti njegov duhovni i teološki smisao - jednom riječju - njegov sensus plenior. ${ }^{66}$ Sav kanon

${ }^{63}$ Usp. PAPINSKA BIBLIJSKA KOMISIJA, Nadahnuće i istina Svetoga pisma, br. 65-83., A. POPOVIĆ, Nadahnuće i istina Svetoga pisma prema dokumentu Papinske biblijske komisije, 1063s.

${ }^{64}$ Usp. PAPINSKA BIBLIJSKA KOMISIJA, Nadahnuće i istina Svetoga pisma, br. 67., 70.

${ }^{65}$ Usp. isto, br. 84-103.

${ }^{66}$ Usp. isto, 103; DV, br. 12; VD, br. 40-41. O tome pitanju vidi: J. RATZINGER / BENEDIKT XVI., Isus iz Nazareta, Split, 2007., 5-17., B. VULIĆ, O jedinstvu i harmoniji Pisma, u: Communio, hrv. izdanje, 42(2016.)126, 2-4. 
Pisma upućuje na jednu jedinu istinu - Krista, Sina Božjega, Očeva objavitelja i spasitelja svijeta.

Taj dokument govori i o poteškoćama tumačenja Riječi Božje jer u Bibliji nalazimo proturječja, povijesne netočnosti, nevjerojatna pripovijedanja, propise i moralna ponašanja iz Staroga zavjeta koja nisu u skladu s Isusovim naukom. Te poteškoće mogu se svesti na dvije vrste: 1 ) povijesna poteškoća javlja se kada se Bibliju čita kao povijesnu kroniku koja bi trebala donijeti povijesne činjenice i izvještaje; 2) socijalno-etička poteškoća nastaje s obzirom na biblijske tekstove koji zagovaraju nasilje, proklinju te potiču na uništenje cijeloga naroda. Kako bi barem djelomično razriješila tu poteškoću, Papinska biblijska komisija poziva se na Dei Verbum 15 koji govori o tome da se u Starome zavjetu nalazi ono što je nesavršeno i uvjetovano vremenom te na Dei Verbum br. 13 koji upozorava na susretljivost vječne Mudrosti; jednako tako referira se i na encikliku Divino afflante Spiritu koja govori o uporabi različitih književnih vrsta od kojih svaka sadrži vlastiti način izražavanja istine. Ako je cijelo Sveto pismo nadahnuto, onda je nedopustivo iz njega odstraniti neugodne dijelove po bilo kojoj osnovi ili problematične tekstove, nego i u njima treba tražiti vrijednost njihove poruke u kontekstu cijeloga pripovijedanja, uvijek $\mathrm{u}$ jedinstvu i harmoniji cijeloga Pisma. ${ }^{67}$ Spomenimo samo po jedan primjer iz Staroga i Novoga zavjeta. Prijelaz preko Crvenoga mora prikazan je kao novo stvaranje. Kao što je Bog stvorio svijet razdvajajući more od suhe zemlje, tako sada na isti način stvara izraelski narod označavajući za njega prijelaz kroz more po suhoj zemlji. Istina opisa ne nalazi se samo u tradiciji koja se spominje nego i u teološkoj interpretaciji koja ga prati. Biblijski tekst objedinjuje drevni opis i aktualizaciju koja je poslije bila izložena. Poruka koja se želi prenijeti jest ta da je Bog danas, kao što je bio i jučer, nazočan uz svoj narod da ga spasi. U Novome zavjetu izvještaji o Isusovu djetinjstvu i njegovoj povijesti odnosa s Izraelom služe kao uvod i tumačenje njegova spasenjskoga djela koje slijedi u nastavku evanđelja ${ }^{68}$ Ukratko, središnja istina Svetoga pisma uvijek je Božje spasenjsko djelo.

\section{Zaključak}

Dogmatsku konstituciju o božanskoj objavi Drugoga vatikanskoga sabora možemo smatrati temeljnicom u daljnjim crkvenim promišljanjima o temama istine i nadahnuća Svetoga pisma, što se lako zaključuje iz postsinodalne apostolske pobudnice Benedikta XVI. Verbum Domini i dokumenta Papinske biblijske komisije Nadahnuće $i$ istina Svetoga pisma. Riječ koja dolazi od Boga i govori o Bogu da spasi svijet iz

\footnotetext{
${ }^{67}$ Usp. PAPINSKA BIBLIJSKA KOMISIJA, Nadahnuće i istina Svetoga pisma, br. 104-105.

${ }^{68}$ Usp. isto, 108., 113.
} 
2014. godine, kao i drugih crkvenih dokumenata kojima je polazna točka i temelj upravo Dei Verbum.

Osobito je dokument Papinske biblijske komisije rasvijetlio narav nadahnuća i istine Svetoga pisma, što je i bila njegova nakana. Cilj toga dokumenta nije bio dokazivati činjenicu nadahnuća biblijskih spisa ${ }^{69}$, što smo mi u jednome dijelu ovoga rada ipak nastojali s pomoću povijesnoga presjeka. Narav nadahnuća nužno je promatrati u povezanosti s objavom, a istinu Svetoga pisma u obzoru vjere. S obzirom na dosadašnji pristup temama nadahnuća i istine Svetoga pisma posve dijelimo mišljenje s bibličarom Antom Popovićem:

»Dosadašnja obrada tema nadahnuća i istine Biblije u okviru traktata sustavne teologije uvijek je, istina, polazila od odabranih svetopisamskih odlomaka, ali je taj odabir tekstova bio fokusiran na one tekstove u kojima se izričito govori o božanskom nadahnuću prenositelja božanske poruke (npr. proročke knjige ili odabrani novozavjetni tekstovi: 2 Tim 3,15-16; $2 \mathrm{Pt} \mathrm{1,20-}$ 21), dok je manja pozornost posvećivana onim svetopisamskim knjigama u kojima tema nadahnuća nije bila izričito spomenuta (npr. mudrosne knjige). Stoga taj dokument Biblijske komisije predstavlja proširenje svetopisamske podloge za temu nadahnuća i istine Biblije jer istražuje tragove i svjedočanstva o temi nadahnuća i istine u svim glavnim dijelovima kako Starog zavjeta tako i Novoga zavjeta. $\ll^{70}$

S obzirom na odnos prema nadahnuću Svetoga pisma moramo zaključno istaknuti da kada u nama oslabi svijest o nadahnuću Svetoga pisma, tada postoji opasnost da ga se čita samo kao povijesnu knjigu, a ne povijesno-spasenjsku. Tada ono postaje obično štivo koje se čita iz radoznalosti ili puke stručnosti, a ne djelo Duha Svetoga u kojem možemo čuti živu i uvijek djelotvornu uistinu Božju riječ i njegov glas i prepoznati ga nazočna u povijesti spasenja po djelima i riječima povijesno dohvatljivim koje izgovara i čini radi nas i našega spasenja. ${ }^{71}$ Sveto pismo jest Riječ Božja upravo zato što je napisano po nadahnuću Duha Svetoga. Stoga s pravom smijemo upozoriti da »neprepoznavati božansku stvarnost Svetoga pisma značilo bi nečastiti ga kao nadahnutu riječ Božju. Neprepoznavati njegova ljudska obilježja odvelo bi nas u fundamentalizam $\ll^{72}$

${ }^{69}$ Usp. isto, 6.

${ }^{70}$ A. POPOVIĆ, Nadahnuće i istina Svetoga pisma prema dokumentu Papinske biblijske komisije, 1072, bilj. 48.

${ }^{71}$ Usp. VD, br. 19.

${ }^{72}$ KATOLIČKA BISKUPSKA KONFERENCIJA ENGLESKE I WALESA, KATOLIČKA BISKUPSKA KONFERENCIJA ŠKOTSKE, Sveto pismo - Božji dar, 13. 
Zadnji je Koncil izrazio pozitivan stav glede teme istine Svetoga pisma, odustajući od obrambenoga stava sine errore, te je u središte stavio istinu radi našega spasenja. Time nepogrješivost Svetoga pisma nije više viđena kao posljedica nadahnuća, nego je istina predočena kao bît Svetoga pisma stavljajući u prvi plan formalni objekt objave, tj. Boga i njegovo djelo spasenja ljudskoga roda. ${ }^{73}$

Istina o Bogu i njegovu spasenju ljudi, što je središte božanske objave, svoj je vrhunac i puninu zadobila u Kristu, u njegovim riječima i djelima kojima nam je objavio trojstvenoga Boga. Isus objavljuje da je Bog zajedništvo u sebi (Iv 17, 24), ali i to da Bog nudi zajedništvo sa sobom po svome Sinu. Važna kategorija nadahnuća Svetoga pisma pokazuje se kao primjeren i nezaobilazan put za vjerodostojno priopćavanje te istine uvijek i svugdje.

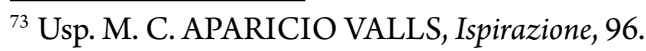




\title{
THE INSPIRATION AND TRUTH OF SACRED SCRIPTURE
}

\author{
Hrvoje KALEM*
}

\begin{abstract}
Summary: Thinking about the inspiration and truth of Sacred Scripture is an indispensable topic in almost every period of church teaching and theology. The first part of the article discusses the nature of inspiration and how it is interpreted, pointing to its broader understanding in later church documents: the Dogmatic Constitution on Divine Revelation of the Second Vatican Council, Dei Verbum, and especially the 2014 document of the Pontifical Biblical Commission entitled The Inspiration and Truth of Sacred Scripture. The Word That Comes from God and Speaks of God for the Salvation of the World. The article points to the importance of inspiration as a carrying term for understanding the sacred text as truly the word of God in words of people. The truth of Sacred Scripture is inextricably linked to this reality. In the second part, the article clarifies that the truth we should seek in Scripture and for which it exists is the truth written in it for our salvation, thereby expressing a positive view about the topic of the truth of Scripture. The entirety of this truth is summarized and fully uttered in the person of Jesus Christ, the Father's revelator and Savior of mankind. Inspiration proves to be a convenient avenue for communicating this truth.
\end{abstract}

Keywords: truth, inspiration, Sacred Scripture, salvation, Word of God, hagiographers, Second Vatican Council.

\footnotetext{
* Asst. Prof. Hrvoje Kalem, Ph. D., Catholic Faculty of Theology in Đakovo, J. J. Strossmayer University of Osijek, P. Preradovića St 17, P. O. box 54, 31400 Đakovo, Croatia, hrvojekalem@gmail.com
} 